\title{
DETEKSI KUALITAS TEMBAKAU BERDASARKAN AROMA BERBASIS
}

\section{ELECTRONIC NOSE}

\author{
Misbah, M. Nurul Arif, Yoedo A.S. \\ Teknik Elektro Fakultas Teknik Universitas Muhammadiyah Gresik \\ Jl.Sumatera No. 101 GKB, Gresik \\ E-mail: misbah@umg.ac.id
}

\begin{abstract}
ABSTRAK
Tembakau mempunyai aroma khas, yang dihasilkan dari bahan organik yang mudah menguap dan yang tidak mudah menguap. Kualitas tembakau ditentukan dari proses fermentasi dan pengeringan. Pada industri rokok, penentuan kualitas tembakau dilakukan oleh tenaga ahli dengan mengandalkan indra penciuman. Hal ini berpotensi menghasilkan tingkat kesalahan yang tinggi. Electronic nose dapat dijadikan salah satu solusi dalam menentukan kualitas tembakau. Electronic nose terdiri dari beberapa sensor gas dan unit pengolah data. Sensor gas yang dipakai adalah MQ4, MQ7, MQ 135 dan MQ137. Sedangkan pada unit pengolah data terdapat algoritma kecerdasan buatan menggunakan neural network. Neural network terdiri dari 4 neuron pada input layer, 25 neuron pada hidden layer dan 2 neuron pada output layer dengan fungsi aktivasi TanSig. Dari hasil pengujian sistem ini dapat mengidentifikasi tembakau yang baik, sedang dan jelek dengan tingkat keakurasiaan $95 \%$.
\end{abstract}

Kata kunci: Electronic nose, sensor gas, tembakau.

\begin{abstract}
ABSTRACK
Tobacco has a distinctive aroma, which is produced from volatile and non-volatile organic materials. Tobacco quality is determined by the fermentation and drying processes. In the cigarette industry, tobacco quality is determined by experts by relying on the sense of smell. This has the potential to result in a high error rate. Electronic nose can be used as a solution in determining the quality of tobacco. The electronic nose consists of several gas sensors and a data processing unit. The gas sensors used are MQ4, MQ7, MQ 135 and MQ137. While in the data processing unit there is an artificial intelligence algorithm using a neural network. The neural network consists of 4 neurons in the input layer, 25 neurons in the hidden layer and 2 neurons in the output layer with the TanSig activation function. From the results of testing this system can identify tobacco that is good, moderate and bad with an accuracy rate of $95 \%$.
\end{abstract}

Keywords: Electronic nose, gas sensor, tobacco. 


\section{PENDAHULUAN}

Tembakau merupakan bahan baku utama dalam industri pembuatan rokok. Beberapa negara, seperti Brazil, America, Europe, Zimbabwe, China, India, Malawi, Russia dan Indonesia, tembakau merupakan komoditi perkebunan yang mempunyai nilai tinggi [1].

Bahan baku utama pada industri rokok adalah tembakau, oleh karena itu kualitasnya harus tetap dijaga. Salah satu parameter dalam menentukan kualitas tembakau adalah aroma. Aroma tembakau didapat darizat yang terkandung didalamnya. Ada yang bersifat volatile dan nonvolatile [2]. Aroma tembakau dipengaruhi oleh lama proses pengeringan dan fermentasi.

Ada beberapa literatur yang menggunakan metode gas kromatografi untuk menganalisa zatzat kimia yang terkandung dalam tembakau. Metode ini memerlukan peralatan yang kompleks dan butuh pengkondisian dalam melakukan pengujian, sehingga membutuhkan waktu yang lama [3][4].

Untuk menentukan kualitas tembakau dibutuhkan pengujian yang cepat dan akurat. Teknologi electronic nose merupakan salah satu solusi yang dapat digunakan dalam menentukan kualitas tembakau. Electronic nosetelah digunakan secara luas baik untuk monitoring lingkungan [5][6], perpaduan electronic nose dengan neural network digunakan untuk identifikasi, antara lain deteksibahan beracun [7], menentukan kualitas ikan [8] dan deteksi kualitas tembakau [9][10].

Penelitian sebelumnya telah dibuat sistem electronic nose untuk menentukan kualitas tembakau dengan menggunakan metode learning vector quantization (LVQ). Hasil klasifikasinya sebesar 93\% [11].

Pembahasan pada makalah ini adalah untuk memperbaiki penelitian sebelumnya. Metode neural network digunakan dalam menentukan kualitas tembakau berdasarkan aroma yang dihasilkan selama proses fermentasi. Ada tiga kelas yang akan dideteksi, yaitu kelas 1 saat difermentasi selama 3 minggu, kelas 2 selama 4 minggu dan kelas 3 selama 8 minggu. Tembakau yang dipakai pada industri rokok adalah yang difermentasi selama 8 minggu.

\section{METODE}

Electronic noseterdiri dari beberapa sensor gas dan unit pengolah data. unit pengolah data terdapat algoritma kecerdasan buatan yaitu neural network.

\section{Sensor Gas}

Tembakau mengandung komponen volatile sebanyak 300 macam yang berperan dalam 
memberikan aroma khas pada tembakau. Beberapa komponen volatileadalah protein, nikotin, pati, polypenol, magnesium ( $\mathrm{Mg})$, calcium (Ca), phosphor $(\mathrm{P}), \mathrm{Zn}$, potassium, $\mathrm{Cu}$ dan lainnya [12].Tabel 1menunjukkan sensor gas yang dipilih beserta keterangannya.

Tabel1.Sensor yang digunakan pada electronic

nose.

\begin{tabular}{cc}
\hline Sensor & Respon \\
\hline MQ4 & Methane \\
MQ7 & Karbon Monoksida $(\mathrm{CO})$ \\
MQ135 & $\mathrm{NH}_{3}$, Benzene, Smoke \\
MQ137 & Ammonia $\left(\mathrm{NH}_{3}\right)$, Ethanol \\
\hline
\end{tabular}

\section{Neural Network}

Arsitektur neural network yang digunakan adalah multilayer perceptron dengan 3 layer, yaitu input layer, hidden layer, dan output layerseperti pada Gambar 4. Pada input layer terdapat 4 node yang menerima input dari 4 sensor. Pada hidden layerterdapat 25neuron dan pada output layer terdapat 1neuron. Output yang dihasilkan berupa 3 kelas. Proses kalkulasi dari dinyatakan sebagai berikut:

$$
\left\{x_{1}, t_{1}\right\},\left\{x_{2}, t_{2}\right\}, \ldots,\left\{x_{n}, t_{n}\right\}
$$

$$
z_{-} n e t_{j}=\sum_{j=1}^{k} v_{i j} \cdot x_{j}+v_{0 j}
$$

dimana $z_{-}$net $_{i}$ adalah neuroni, $\mathrm{k}$ neuron maksimal dari neuron j, $v_{i j}$ adalah bobotdari neuroni hingga $\mathrm{j}, x_{j}$ adalah data input pada neuron $\mathrm{j}$, dan $v_{0 j}$ adalah bias pada neuroni.

$$
z_{j}=f_{1}\left(z_{-} n e t_{j}\right)=\frac{1}{1+e^{-z_{-} n e t_{j}}}
$$

dimana $Z_{j}$ adalah output dari neuron pada hidden layer dengan menggunakan fungsi aktivasi sigmoid.

$y_{k}=f_{2}\left(y_{-} n e t_{k}\right)=\frac{1}{1+e^{-y_{-} n e t_{k}}}$

$e_{k}=t_{k}-y_{k}$

$e=\frac{1}{2} \sum_{j=1}^{i}\left(t_{k}-y_{k}\right)^{2}$

dimana $e_{k}$ adalah error pada output, $t_{k}$ adalah output target pada neuronk, $y_{k}$ adalah output pada neuronk, eadalah root mean square error.

$$
\dot{f}_{2}\left(y_{\_} n e t_{k}\right)=f_{2}\left(y_{\_} n e t_{k}\right)\left[1-f_{2}\left(y_{-} n e t_{k}\right)\right](12
$$

dimana $\dot{f}_{2}\left(y_{-} n e t_{k}\right)$ adalah transfer function dari turunan sigmoid dan $f\left(y_{-} n e t_{k}\right)$ merupakan transfer function dari sigmoid.

dimana $x$ merupakan input dan $t$ adalah nilai target. 


$$
\begin{aligned}
& \delta_{k}=e_{j}\left(y_{-} n e t_{k}\right) \dot{f}_{2}\left(y_{-} n e t_{k}\right) \\
& \delta_{n e t_{j}}=\sum_{k=1}^{m} \delta_{k} w_{j k} \\
& \delta_{j}=\text { Snet }_{j} \dot{f}_{1}\left(z_{-} n e t_{j}\right)=\text { Snet }_{j} z_{j}\left(1-z_{j}\right)
\end{aligned}
$$

dimana $\delta_{k}$ merupakan gradien dari neuronk.

$$
\begin{aligned}
& \Delta w_{j k}(n)=\alpha \delta_{k}(n)+\varphi \Delta w(n-1) z_{j} \\
& w_{j k}(n+1)=w_{j k}(n)+\Delta w_{j k}(n) \\
& \Delta v_{i j}(n)=\alpha \delta_{j}(n)+\varphi \Delta v(n-1) x_{i} \\
& v_{i j}(n+1)=v_{i j}(n)+\Delta v_{i j}(n)
\end{aligned}
$$

dimana $w_{j k}(n+1), \Delta w_{j k}(n) \quad$ adalah nilai perubahan weight. $\Delta w(n-1)$ adalah nilai perubahan weight iterasi sebelumnya, $\delta(n)$ adalah gradien dari layer sebelumnya, dimana $\varphi$ adalah nilai momentum, $\alpha$ adalah learning rate dan $Z_{j}$ nilai layer.

$$
\begin{aligned}
& \Delta b(n)=\alpha \delta(n)+\varphi \Delta b(n-1) \\
& b(n+1)=b(n)+\Delta b(n)
\end{aligned}
$$

dimana $b(n+1)$ adalah bias yang baru dan $b(n)$ merupakan bias awal.

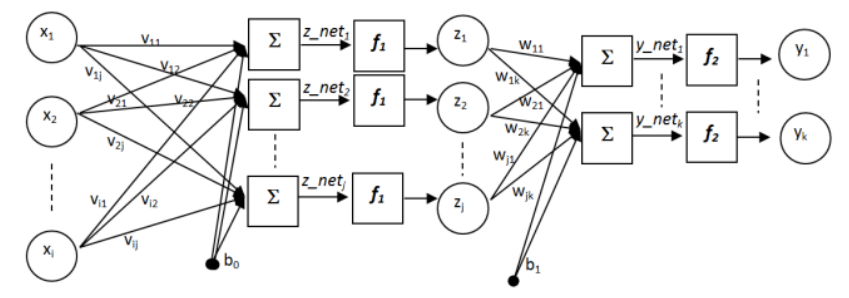

Gambar 1. Arsitektur Neural Network.

Perancangan sistem electronic noseinimenggunakan sensor gas dengan metode pengenalan pola neural network. Bagian perangkat keras terdiri dari modul Arduino Uno versi R3, modul Bluetooth HC-05, Modul LCD 16 x 2, sensor suhu dan kelembapan DHT-11, 4 Modul sensor gas yang berbeda yaitu MQ-4, MQ-7, MQ135 dan MQ-137 juga beberapa perangkat penunjang sepertifan DC5v sebagai exhaust dankotak sampel. Desain alat untuk percobaan seperti terlihat pada Gambar 2. Sedangkan hubungan antar komponen perangkat keras pada electronic nose terlihat pada Gambar 3.

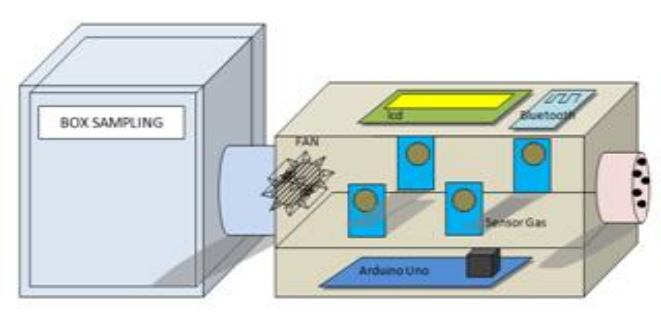

Gambar 2. Desain sistem untuk percobaan 


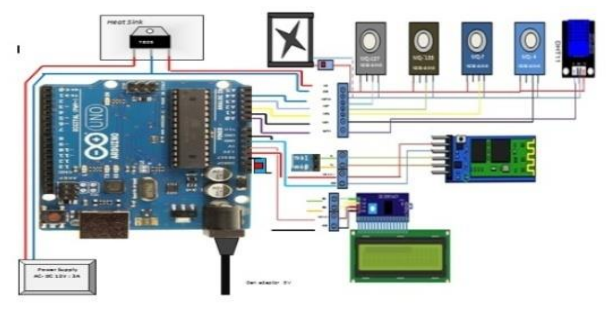

Gambar 3. Perangkat keras sistem E-nose.

\section{HASIL DAN PEMBAHASAN}

Pengambilan data diperoleh dari respon tiap sensor untuk 3 kelas tembakau. Pada tiap kelas tembakau dilakukan 15 kali pengujian. Rata-rata waktu yang dibutuhkan untuk mendapat data dimulai dari respon pertama sampai kondisi stabil adalah 160 detik. Nilai yang tersimpan pada komputer masih dalam nilai ADC. Resolusi ADC yang digunakan sebesar 10 bit. Respon sensor saat ada paparan uap tembakau terlihat pada Gambar 4.

Data yang tersimpan berupa data ADC sebanyak 160 titik untuk masing-masing sensor. Kemudian diambil rata-ratanya untuk dijadikan masukan, baik sebagai data latih maupun data uji pada algoritma neural network. Tabel 2 menunjukkan data latih untuk tembakau kelas 1 (3 minggu), kelas 2 (4 minggu) dan kelas 3 (8 minggu).

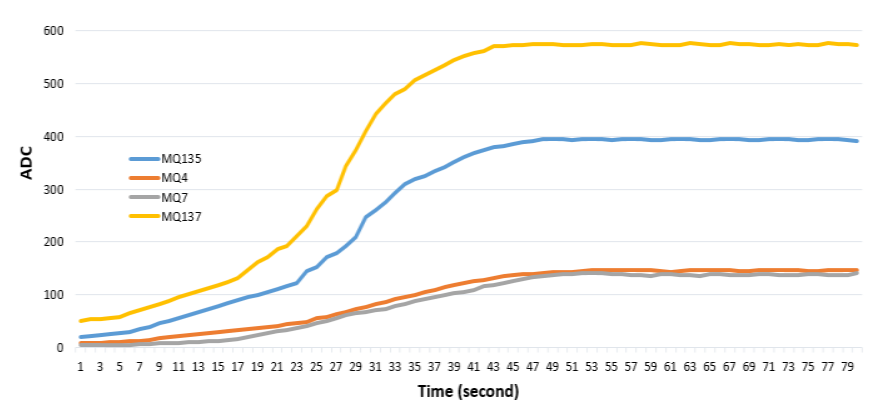

Gambar 4. Respon sensor saat terpapar bau tembakau

Tabel 2.Data latih pada masing-masing kelas

\begin{tabular}{|c|c|c|c||c|c|c|c||c|c|c|c|}
\hline \multicolumn{5}{|c||}{ Kelas 1 } & \multicolumn{4}{c||}{ Kelas 2 } & \multicolumn{4}{c|}{ Kelas 3 } \\
\hline MQ135 & MQ4 & MQ7 & MQ137 & MQ135 & MQ4 & MQ7 & MQ137 & MQ135 & MQ4 & MQ7 & MQ137 \\
\hline 400 & 142 & 143 & 573 & 373 & 144 & 145 & 567 & 445 & 143 & 141 & 610 \\
\hline 394 & 141 & 141 & 572 & 390 & 141 & 142 & 563 & 524 & 156 & 143 & 704 \\
\hline 456 & 153 & 151 & 615 & 383 & 139 & 142 & 554 & 480 & 149 & 141 & 672 \\
\hline 431 & 148 & 149 & 582 & 375 & 142 & 144 & 551 & 562 & 170 & 166 & 792 \\
\hline 438 & 141 & 141 & 612 & 366 & 141 & 144 & 510 & 455 & 149 & 144 & 645 \\
\hline 429 & 141 & 143 & 582 & 368 & 142 & 139 & 500 & 451 & 142 & 139 & 645 \\
\hline 400 & 153 & 151 & 612 & 383 & 142 & 142 & 489 & 442 & 134 & 142 & 700 \\
\hline
\end{tabular}

Gambar 5 menunjukkan pola respon pada sensor untuk tembakau kelas 1, kelas 2 dan kelas 3 terhadap nilai ADC. Dari respon tersebut dapat dijelaskan bahwa nilai ADC pada sensor MQ7 (karbon monoksida) dan MQ4 untuk masingmasing kelas memiliki nilai hampir sama (140 150).Sedangkan pada sensor MQ135 dan MQ137 mempunyai nilai ADC antara 400 - 700. Nilai kedua sensor ini tinggi disebabkan adanya senyawa alkohol yang dihasilkan dari proses fermentasi zat pati pada tembakau. 
Volume 16 Nomor 1 (2021) 37-45

E - Link P-ISSN 1858-2109 E-ISSN 2656-5676 Jurnal Teknik Elektro dan Informatika

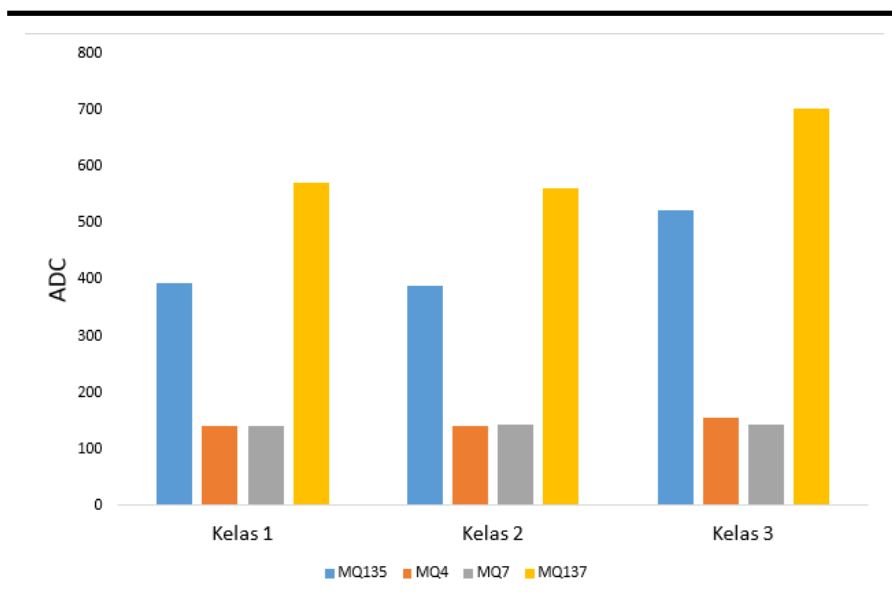

Gambar 5. Pola respon sensor gas untuk masingmasing kelas

Tabel 3. Data uji ternormalisasi

\begin{tabular}{crrrr}
\hline Data & \multicolumn{4}{c}{ Sensor } \\
\cline { 2 - 5 } Uii & MQ135 & \multicolumn{1}{c}{ MQ4 } & \multicolumn{1}{c}{ MQ7 } & \multicolumn{1}{c}{ MQ137 } \\
\hline 1 & 0.508861 & 0.177215 & 0.177215 & 0.721519 \\
2 & 0.502532 & 0.181013 & 0.182278 & 0.726582 \\
3 & 0.573418 & 0.189873 & 0.193671 & 0.779747 \\
4 & 0.548101 & 0.18481 & 0.186076 & 0.734177 \\
5 & 0.551899 & 0.181013 & 0.179747 & 0.772152 \\
6 & 0.565823 & 0.179747 & 0.178481 & 0.734177 \\
7 & 0.508861 & 0.194937 & 0.193671 & 0.772152 \\
8 & 0.506329 & 0.179747 & 0.178481 & 0.722785 \\
9 & 0.501266 & 0.179747 & 0.181013 & 0.725316 \\
10 & 0.544304 & 0.187342 & 0.189873 & 0.789873 \\
11 & 0.507595 & 0.177215 & 0.181013 & 0.721519 \\
12 & 0.550633 & 0.182278 & 0.178481 & 0.76962 \\
13 & 0.564557 & 0.177215 & 0.179747 & 0.737975 \\
14 & 0.503797 & 0.179747 & 0.178481 & 0.73038 \\
15 & 0.553165 & 0.182278 & 0.183544 & 0.774684 \\
16 & 0.473418 & 0.186076 & 0.187342 & 0.713924 \\
17 & 0.496203 & 0.179747 & 0.181013 & 0.711392 \\
18 & 0.486076 & 0.177215 & 0.178481 & 0.7 \\
19 & 0.475949 & 0.178481 & 0.183544 & 0.696203 \\
20 & 0.460759 & 0.179747 & 0.183544 & 0.646835 \\
21 & 0.464557 & 0.181013 & 0.177215 & 0.635443 \\
22 & 0.482278 & 0.178481 & 0.181013 & 0.617722
\end{tabular}

\begin{tabular}{rrrr}
0.472152 & 0.18481 & 0.186076 & 0.717722 \\
0.497468 & 0.181013 & 0.182278 & 0.712658 \\
0.487342 & 0.178481 & 0.179747 & 0.701266 \\
0.486076 & 0.179747 & 0.181013 & 0.698734 \\
0.48481 & 0.178481 & 0.179747 & 0.7 \\
0.462025 & 0.182278 & 0.181013 & 0.648101 \\
0.464557 & 0.182278 & 0.179747 & 0.649367 \\
0.494937 & 0.178481 & 0.182278 & 0.708861 \\
0.564557 & 0.182278 & 0.179747 & 0.774684 \\
0.664557 & 0.194937 & 0.182278 & 0.892405 \\
0.608861 & 0.189873 & 0.181013 & 0.851899 \\
0.710127 & 0.216456 & 0.207595 & 1 \\
0.572152 & 0.186076 & 0.179747 & 0.813924 \\
0.572152 & 0.181013 & 0.177215 & 0.817722 \\
0.562025 & 0.172152 & 0.182278 & 0.888608 \\
0.565823 & 0.183544 & 0.181013 & 0.775949 \\
0.665823 & 0.196203 & 0.183544 & 0.893671 \\
0.610127 & 0.191139 & 0.182278 & 0.853165 \\
0.567089 & 0.183544 & 0.181013 & 0.778481 \\
0.662025 & 0.192405 & 0.179747 & 0.887342 \\
0.611392 & 0.194937 & 0.182278 & 0.85443 \\
0.558228 & 0.170886 & 0.179747 & 0.887342 \\
0.567089 & 0.18481 & 0.183544 & 0.777215 \\
\hline
\end{tabular}

Proses learning pada neural network menggunakan 21 data latih. Proses tersebut dilakukan di komputer dengan jumlah iterasi sebanyak 5.000 dan nilai error yang dihasilkan adalah 0.001. Pada proses ini, nilai weight dan bias terbaik akan digunakan untuk melakukan identifikasi. Proses validasi pada neural network dilakukan dengan 45data diluar data latih, masingmasing kelas terdiri dari 15 data seperti tercantum pada Tabel 3. Secara berturut-turut data kelas 1 dari nomer 1-15, kelas 2 nomer 16-30 dan kelas 3 nomer 31-45. Setelah dilakukan pengujian 
Volume 16 Nomor 1 (2021) 37-45

E - Link P-ISSN 1858-2109 E-ISSN 2656-5676

Jurnal Teknik Elektro dan Informatika

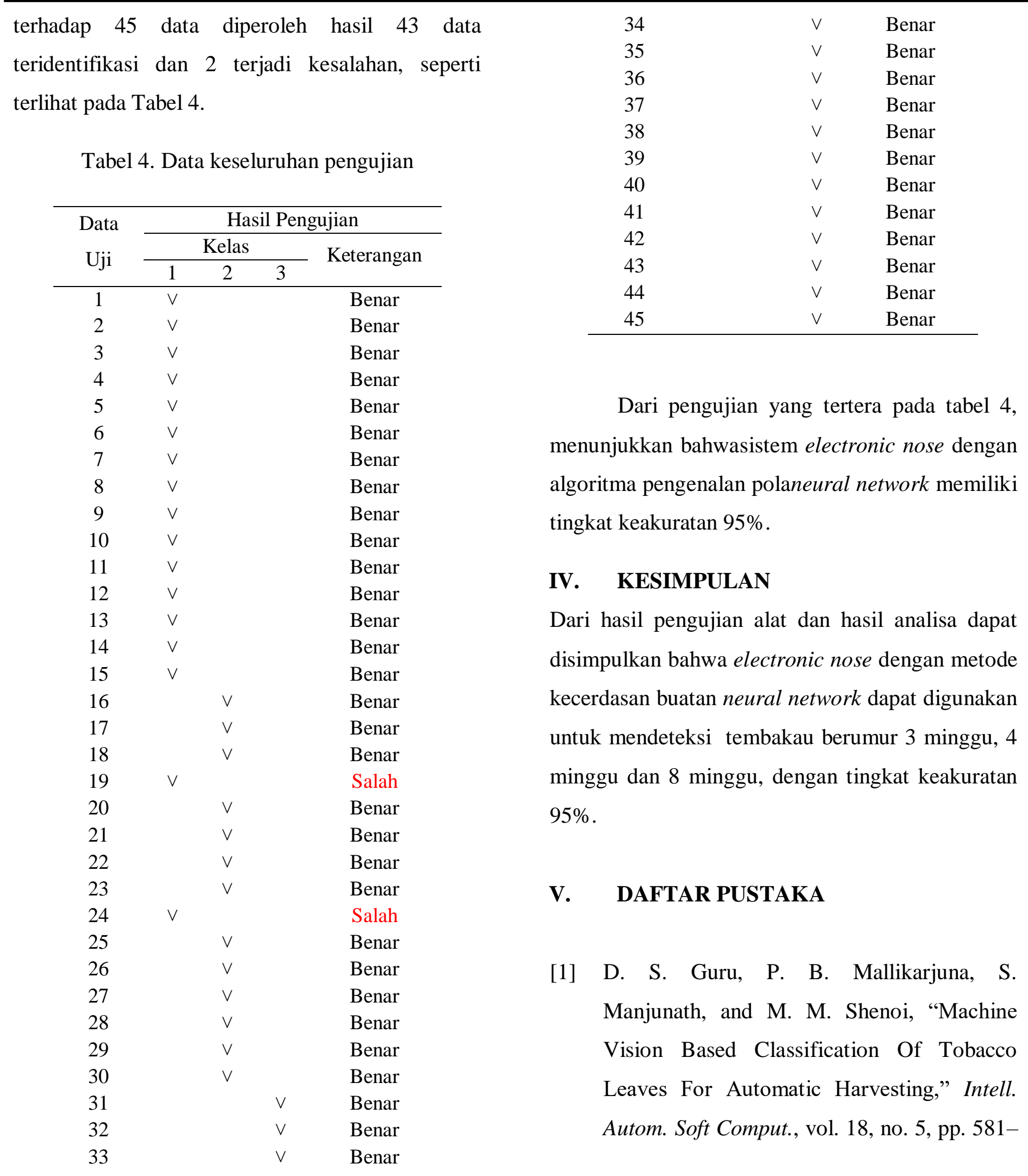


Volume 16 Nomor 1 (2021) 37-45

E - Link P-ISSN 1858-2109 E-ISSN 2656-5676

Jurnal Teknik Elektro dan Informatika

590, 2012, doi:

10.1080/10798587.2012.10643267.

[2] C. Gong, Y. Zhou, H. Yang, "Introduction for three stage curing of flue-cured tobacco,"Beijing: Science Press.

[3] T. Miyake and T. Shibamoto, "Quantitative analysis by gas chromatography of volatile carbonyl compounds in cigarette smoke," J. Chromatogr. A, vol. 693, no. 2, pp. 376-381, Feb. 1995, doi: 10.1016/00219673(94)01179-I.

[4] L. Kim and P. J. Marriott, "Preparative gas chromatography," in Gas Chromatography, Elsevier, 2021, pp. 487-504.

[5] Misbah, R. P. Astutik, Eliyani, H. A. Winarno, A. Muklish and D. Andesta, "Communication System on Wireless Sensor Networks using Raspberry Pi and Arduino for Monitoring Gas of Air Pollution," in International Seminar on Intelligent Technology and Its Applications (ISITIA), 2018, pp. 27-32, doi: 10.1109/ISITIA.2018.8711371.

[6] F. Ardiansyah, Misbah, and P. P. S. Saputra, "Sistem Monitoring Debu Dan Karbon
Monoksida Pada Lingkungan Kerja Boiler Di Pt. Karunia Alam Segar," IKRA-ITH Teknol. J. Sains Teknol., vol. 2, no. 3, pp. 62-71, 2018, [Online]. Available: https://journals.upiyai.ac.id/index.php/ikraithteknologi/article/view/333.

[7] Misbah, M. Rivai, and F. Kurniawan, "Quartz crystal microbalance based electronic nose system implemented on Field Programmable Gate Array," Telkomnika (Telecommunication Comput. Electron. Control., vol. 17, no. 1, pp. 370-376, 2019, doi: 10.12928/TELKOMNIKA.v17i1.10133.

[8] M. Rivai, Misbah, M. Attamimi, M. Hamka Firdaus, Tasripan, and Tukadi, "Fish Quality Recognition using Electrochemical Gas Sensor Array and Neural Network," in International Conference of Computer Engineering, Network, and Intelligent Multimedia, 2019, pp. 29-33.

[9] Y. Sari and R. A. Pramunendar, "Classification Quality of Tobacco Leaves as Cigarette Raw Material Based on Artificial Neural Networks," Int. J. Comput. Trends Technol., vol. 50, no. 3, pp. 147-150, 2017, doi: 10.14445/22312803/ijctt-v50p126. 
[10] M. Rivai, "Klasifikasi Tembakau Menggunakan Deret Sensor Tin-Oxide dan Neural Network,"JAVA Journal of Electronics Engineering, Vol. 9, No.2, 2011.

[11] M. Arif, Misbah, and Y. A. Surya,"Klasifikasi Aroma Tembakau Menggunakan Learning Vector Quantization,'E-Link: Jurnal Teknik Elektro dan Informatika, 14(2), pp. 90-95, 2019. doi:10.30587/e-link.v14i2.1198

[12] Tirtosastro, Samsuri, A. S. Murdiyati,. "Kandungan Kimia Tembakau dan Rokok,"Buletin Tanaman Tembakau, Serat dan Minyak Industri 2 (1). 33-34, 2010, ISSN 2085-6717. 